\title{
EFFECTS OF THE HERBICIDE ROUNDUP ON FRESHWATER MICROBIAL COMMUNITIES: A MESOCOSM STUDY
}

\author{
G. L. Pérez, ${ }^{1,5}$ A. Torremorell,${ }^{1}$ H. Mugni, ${ }^{2}$ P. Rodríguez,${ }^{3}$ M. Solange Vera, ${ }^{3}$ M. do Nascimento, ${ }^{3}$ \\ L. Allende, ${ }^{3}$ J. Bustingorry, ${ }^{1}$ R. Escaray, ${ }^{1}$ M. Ferraro, ${ }^{1}$ I. Izaguirre, ${ }^{3}$ H. Pizarro, ${ }^{3}$ C. Bonetto, ${ }^{2}$ \\ Donald P. Morris, ${ }^{4}$ And H. Zagarese ${ }^{1}$ \\ ${ }^{1}$ Instituto de Investigaciones Biotecnológicas, Instituto Tecnológico de Chascomús (Intech), CONICET, Camino Circunvalación \\ Laguna Km 6, CC 164, 7130, Chascomús, Argentina \\ ${ }^{2}$ Instituto de Limnología Dr. Ringuelet, Avenida Calchaquí km 23.5, 1888, Florencio Varela, Buenos Aires, Argentina \\ ${ }^{3}$ Departamento de Ecología, Genética y Evolución, Facultad de Ciencias Exactas y Naturales, Universidad de Buenos Aires, \\ Buenos Aires, Argentina \\ ${ }^{4}$ Department of Earth and Environmental Sciences, Lehigh University, Bethlehem, Pennsylvania 18015 USA
}

Abstract. The impact of the widely used herbicide glyphosate has been mainly studied in terrestrial weed control, laboratory bioassays, and field studies focusing on invertebrates, amphibians, and fishes. Despite the importance of phytoplankton and periphyton communities at the base of the aquatic food webs, fewer studies have investigated the effects of glyphosate on freshwater microbial assemblages. We assessed the effect of the commercial formulation Roundup using artificial earthen mesocosms. The herbicide was added at three doses: a control (without Roundup) and two treatments of 6 and $12 \mathrm{mg} / \mathrm{L}$ of the active ingredient (glyphosate). Estimates of the dissipation rate $(k)$ were similar in the two treatments (half-lives of 5.77 and $7.37 \mathrm{~d}$, respectively). The only two physicochemical parameters showing statistically significant differences between treatments and controls were the downward vertical spectral attenuation coefficient $k_{\mathrm{d}}(\lambda)$, where $\lambda$ is wavelength, and total phosphorus concentration (TP). At the end of the experiment, the treated mesocosms showed a significant increase in the ratio $k_{\mathrm{d}}(490 \mathrm{~nm}) / k_{\mathrm{d}}(550 \mathrm{~nm})$ and an eightfold increase in TP. Roundup affected the structure of phytoplankton and periphyton assemblages. Total micro- and nanophytoplankton decreased in abundance in treated mesocosms. In contrast, the abundance of picocyanobacteria increased by a factor of about 40. Primary production also increased in treated mesocosms (roughly by a factor of two). Similar patterns were observed in the periphytic assemblages, which showed an increased proportion of dead: live individuals and increased abundances of cyanobacteria (about 4.5-fold). Interestingly, the observed changes in the microbial assemblages were captured by the analysis of the pigment composition of the phytoplankton, the phytoplankton absorption spectra, and the analysis of the optical properties of the water. The observed changes in the structure of the microbial assemblages are more consistent with a direct toxicological effect of glyphosate rather than an indirect effect mediated by phosphorus enrichment.

Key words: glyphosate; herbicide; optical properties; periphyton; phytoplankton; pigments; primary production; Roundup; water chemistry; wetlands.

\section{INTRODUCTION}

The structure of natural communities, the richness and diversity of species, and the interactions among them have profound implications for ecosystem functioning, modulating the fluxes of energy and materials within and among environments (Pratt et al. 1997). Human activities have directly or indirectly added novel stressors to natural aquatic ecosystems, (i.e., climate change, eutrophication, chemical contamination), which have the potential for affecting the structure and function of natural communities. Among these stressors,

Manuscript received 23 March 2007; accepted 5 April 2007; final version received 3 May 2007. Corresponding Editor: R. A. Relyea.

${ }^{5}$ E-mail: gperez@intech.gov.ar herbicides and insecticides have been reported to cause dramatic changes in freshwater environments (e.g., Gustavson et al. 2003, Relyea 2005a, b, Rohr and Crumrine 2005).

Given our incipient and fragmentary understanding of the effects that pesticides have on natural communities (Pratt et al. 1997, Rohr and Crumrine 2005), our ability to accurately forecast the consequences of their use is rather limited. This state of affairs is aggravated in freshwater ecosystems as many pesticides accumulate and concentrate in water bodies (Streit 1992). Since the mid-1990s, the global production of genetically modified herbicides-resistant crops has increased steadily (James 2003). Unfortunately, our understanding and ability to predict future impacts of this new technology have not kept pace with the tremendous expansion of arable land dedicated to these new cultures. 
In Argentina, over 13 million ha of arable land are dedicated to the production of transgenic, glyphosateresistant (GR) soy and, together with Canada and the United States, contributes to most of the global acreage cultured with GR crops. Presently, Argentina is the second largest world producer of GR soy $(30 \mathrm{Mg} / \mathrm{yr})$. This production has been accompanied by an increase in the use of glyphosate (over 60 million L between 1998 and 1999) applied at a rate of up to $10 \mathrm{~L} /$ ha (Lapitz et al. 2004). Thus, the substitution of traditional crops by GR soy within the last couple of decades represents a largescale, unplanned, ecological experiment, whose consequences for natural ecosystems, and aquatic environments in particular, are poorly understood.

Here, we report the results of an outdoor study performed in earthen experimental mesocosms, aimed at identifying the potential effects of Roundup on natural freshwater assemblages. Mesocosms are valuable tools that complement conventional toxicity tests by bringing experimentation one step closer to nature (SETACRESOLVE 1992). In this study, we have measured the loss rate of glyphosate from the experimental units and recorded Roundup effects on a large number of physicochemical and biological parameters (focused on phytoplankton and periphyton assemblages).

Glyphosate [N-(phosphonomethyl)glycine] is a broad spectrum, post-emergent herbicide widely used in agriculture and silviculture for the control of grasses, sedges and broad-leaved weeds (Goldsborough and Brown 1988). The commercial formulation Roundup contains $480 \mathrm{~g} / \mathrm{L}$ of glyphosate, as the isopropylamine salt. Glyphosate's primary mode of action in plants and several microorganisms is the disruption of aromatic amino acid biosynthesis (Duke et al. 2003), through the inhibition of the enzyme 5-enolpyruvyl shikimic acid-3phosphate (EPSP), which halts the production of chorismate. The process ultimately results in the reduction of aromatic amino acids, which in turn reduces or halts protein synthesis, causing cessation of growth and eventually cellular disruption and death. In addition to its main mode of action, glyphosate is known to impair a number of cellular structures and other biochemical processes, such as disruption of chloroplasts, membranes and cell walls, and the alteration of nucleic acid synthesis, photosynthesis, and respiration (e.g., Campbell et al. 1976, Ali and Fletcher 1978, Hernando et al. 1989, Schaffer and Sebetich 2004).

Under field conditions, glyphosate is usually assumed to be rapidly and tightly adsorbed to soil particulates. Consequently, it is generally thought to have negligible off-target mobility from soils to ground or surface waters (Roy et al. 1989, Duke et al. 2003). Nevertheless, off-target displacements of glyphosate have been reported by several authors. Glyphosate may reach aquatic systems either by accidental or wind driven drift of the herbicide spray, or by surface runoff of suspended particulate matter (Bowmer 1982, Goldsborough and
Beck 1989, Feng et al. 1990, U.S. Environmental Protection Agency 1993). Adsorption of glyphosate to soil particulates is determined by chemical and physical characteristic of soils, which in turn affect the potential for off-target movement of the herbicide through water runoff or subsurface flow. Interestingly, given that glyphosate is bound to soil through its phosphonic acid moiety, the addition of inorganic phosphorus could potentially release glyphosate from soil particles (Franz et al. 1997, Pechlaner 2002) through competition for sorption sites. In Argentina, the use of fertilizers has increased about 10 times in the last decade in relation with the agricultural development (Instituto Nacional de Tecnologías Agropecuarias 2003, Lapitz et al. 2004), increasing the likelihood of transporting glyphosate to aquatic ecosystems.

Once in the aquatic environment, glyphosate may become toxic to living organisms, including plants, animals, and microorganisms. Although glyphosate has been widely used and studied in terrestrial weed control, comparatively fewer studies have assessed its effects on natural aquatic biota (Austin et al. 1991, Pechlaner 2002). Among the latter, most studies have used laboratory bioassays to assess the effects of glyphosate on aquatic organisms (e.g., Hartman and Martin 1985, Gardner et al. 1997, Relyea 2004, Schaffer and Sebetich 2004). Field studies, on the other hand, have mostly focused on fish, especially salmonids (Mitchell et al. 1987, Servizi et al. 1987, Wan et al. 1989), invertebrates (Folmar et al. 1979, Kreutzweiser et al. 1989), and amphibians (e.g., Relyea 2005a, b, Relyea et al. 2005). Despite the importance of phytoplankton and periphyton communities at the base of the aquatic food webs, fewer studies have investigated the effects of glyphosate on freshwater microbial communities (Pechlaner 2002).

\section{Materials ANd Methods \\ Experimental design}

An experiment was carried out in 10 artificial earthen ponds (i.e., mesocosms) that were $1.2 \mathrm{~m}$ deep and had a surface area of $25 \mathrm{~m}^{2}$. We assayed three concentrations of the herbicide Roundup: control (without Roundup, four replicates), low dose (nominal glyphosate concentration $6 \mathrm{mg}$ active ingredient/L, three replicates), and high dose (nominal glyphosate concentration $12 \mathrm{mg}$ active ingredient/L, three replicates). These nominal concentrations were chosen to be comparable to the concentrations assayed by other authors (Goldsborough and Brown 1988, Schaffer and Sebetich 2004, Relyea 2005a). The assayed concentrations were slightly higher than those recommended for aquatic and terrestrial weed control (3.7 mg active ingredient/L [Giesy et al. 2000]), or those measured in natural environments (up to $2.6 \mathrm{mg}$ active ingredient/L [Newton et al. 1984, Goldsborough and Brown 1989, Feng et al. 1990, Thompson et al. 2004]). Thus, the assayed concentrations represent a worst-case scenario. As far as we know, 
there is no information of measured glyphosate concentrations in standing natural waters of Argentina.

Water samples were collected from each mesocosm on four occasions using a Van Dorn-style bottle. The first samples were collected either immediately before application (for most variables) or immediately after application (for glyphosate determination). The remaining samples were collected at 1, 6, and 11 days after herbicide application. The samples were poured into 5L plastic containers from which subsamples were taken for glyphosate determinations and analyses of physical, chemical, and biological variables. The study of the periphyton assemblage was performed using artificial substrates, which were placed in each mesocosm 25 days before the beginning of the experiment to allow for substantial colonization.

\section{Glyphosate residual analysis}

Analyses of glyphosate were carried out on water samples filtered through $0.45-\mu \mathrm{m}$ membrane filter. The analyses were performed by reversed-phase HPLC (high performance liquid chromatography) following derivatization with fluorenylmethyl chloroformate chloride (FMOC chloride), following Miles et al. (1986).

\section{Optical properties}

Vertical profiles of ultraviolet (UV) and photosynthetically active radiation (PAR, 400-700 nm) downward irradiance were obtained with a submersible profiling radiometer (Eldonet, Erlangen, Germany). In addition, spectral information was collected using a spectral radiometer (USB2000; Ocean Optics, Dunedin, Florida, USA). Monochromatic and broadband (PAR) attenuation coefficients $k_{\mathrm{d}}(\lambda)$ and $k_{\mathrm{d}}(\mathrm{PAR})$ were calculated by regressing log-transformed irradiance measurements against depth.

The light absorption spectra by total particles $\left[a_{\mathrm{p}}(\lambda)\right]$ were determined after concentration of the particles on $\mathrm{GF} / \mathrm{F}$ filters following the filter pad technique (Trüper and Yentsch 1967). The path length amplification factor ( $\beta$ factor) was determined according to Mitchell and Kiefer (1988) and Bricaud and Stramski (1990). After measuring the absorption of total particulate matter, the spectral absorption of non-algal material $\left[a_{\mathrm{d}}(\lambda)\right]$ was measured separately following Kishino et al. (1984). The absorption coefficients of viable phytoplankton $\left[a_{\mathrm{ph}}(\lambda)\right]$ were obtained by subtracting the bleached matter absorption $\left[a_{\mathrm{d}}(\lambda)\right]$ from the absorption by total particulate matter $\left[a_{\mathrm{p}}(\lambda)\right]$.

The spectral absorption by chromophoric dissolved organic matter (CDOM) was measured on $0.2-\mu \mathrm{m}$ filtered water in quartz cuvettes $(0.01 \mathrm{~m}$ path length) against a distilled water blank. The absorption coefficients due to CDOM $\left[a_{\mathrm{g}}(\lambda)\right]$ were calculated following Kirk (1994). Optical densities were measured using a Hitachi U-2000 spectrophotometer (Hitachi, Tokyo, Japan) in the spectral range of $400-750 \mathrm{~nm}$ at $1-\mathrm{nm}$ intervals.

\section{Chemical analysis}

Given that glyphosate dissipation kinetics in natural waters is likely to be site specific, due to the variety of chemical, physical, and biological variables, the physical and chemical properties of the mesocosms' water were characterized as fully as possible. Water for chemical analysis was filtered immediately after sampling through Whatman GF/C filters. Soluble reactive phosphorus (SRP) was measured by the molybdate-ascorbic method, $\mathrm{NO}_{3}{ }^{-}$and $\mathrm{NO}_{2}{ }^{-}$by $\mathrm{Cd}$ reduction followed by diazotation and $\mathrm{NH}_{4}^{+}$by the indophenol blue method, following the American Publication Health Association (1998). $\mathrm{Ca}^{2+}$ and $\mathrm{Mg}^{2+}$ (atomic absorption spectrometry), $\mathrm{Na}^{+}$and $\mathrm{K}^{+}$(flame photometry), $\mathrm{HCO}^{3-}$ (titration), $\mathrm{SO}_{4}{ }^{2-}$ (turbidimetry), and $\mathrm{Cl}^{-}\left(\mathrm{AgNO}_{3}\right.$ titration) were determined following the American Publication Health Association (1998). Suspended matter was determined as the mass difference after filtration through the Whatman $\mathrm{GF} / \mathrm{C}$ filters. The filters were pre-combusted to $550^{\circ} \mathrm{C}$ for 2 hours prior to use.

Aliquots of filtered water were stored at $4^{\circ} \mathrm{C}$ until analysis of DOC (dissolved organic carbon). DOC was measured by a high temperature $\mathrm{Pt}$ catalyst oxidation method (Shimadzu TOC-5000; Shimadzu Scientific Instruments, Columbia, South Carolina, USA). Prior to measurement, samples were sonicated and acidified (with $\mathrm{HCl}$ ).

\section{Enumeration of phytoplanktonic organisms}

The different size fractions of the phytoplankton and bacterioplankton were quantified. Micro- $(>20 \mu \mathrm{m})$ and nanophytoplankton $(2-20 \mu \mathrm{m})$ samples were fixed with $1 \%$ acidified Lugol's iodine solution. Picophytoplankton $(0.2-2 \mu \mathrm{m})$ and bacterioplankton samples were preserved with $2 \%$ ice-cold glutaraldehyde. Counts of micro- and nanophytoplankton were performed using the inverted microscope technique (Utermöhl 1958) at $400 \times$ magnification. The counting error $(<15 \%)$ was estimated according to Venrick (1978). Algal biovolumes were calculated according to Sun and Liu (2003). The picophytoplankton fraction was counted by taking advantage of the autofluorescence of photosynthetic pigments (Caron 1983, Hawley and Whitton 1991). Samples were collected on $0.2-\mu \mathrm{m}$ black polycarbonate filters (Isopore GTPB 02500; Isopore, Billerica, Massachusetts, USA) then mounted on a microscope slide with a drop of immersion oil (Immersol Zeiss 518 F; Zeiss, Jena Germany). Each filter was examined for pigment autofluorescence with a Zeiss Axioplan microscope equipped with an $\mathrm{HBO} 50-\mathrm{W}$ lamp and a filter set for blue light excitation (BP 450-490 nm, FT 510 nm, LP $520 \mathrm{~nm}$ ) and green light excitation (BP $546 \mathrm{~nm}$, FT 580 nm, LP 590 nm) (Wynn-Williams 1992, Rankin et al. 1997). Bacterioplankton were concentrated and counted on polycarbonate filters (as above), which were stained with DAPI (Porter and Feig 1980). Bacteria were counted using an epifluorescence microscope with UV excitation (BP 365 nm, FT 395 nm, LP 397 nm). For 
estimates of both picophytoplankton and bacterioplankton abundance, a minimum of 20 fields and 400 individuals were counted on each slide (error $<15 \%$ ).

\section{Primary production of phytoplankton}

Phytoplankton primary production (PP) was measured by the ${ }^{14} \mathrm{C}$-technique (Steeman-Nielsen 1952). Samples were incubated for $3 \mathrm{~h}$ in $45-\mathrm{mL}$ quartz tubes placed at the surface of an outdoor water bath. For each mesocosm, two samples were incubated at saturating, but not photohinbiting, irradiance levels using neutral density filters in combination with a long-pass cut-off filter at $395 \mathrm{~nm}$ to remove the UV component of sunlight. Irradiance levels were decided based on preliminary production vs. irradiance curves. In addition, a single tube per mesocosm was wrapped with aluminum foil and used as an estimate of dark ${ }^{14} \mathrm{C}$ assimilation. One $\mu \mathrm{Ci}$ of ${ }^{14} \mathrm{C}$-labeled $\mathrm{NaHCO}_{3}$ was added to each tube. After incubation, samples were filtered through $\mathrm{GF} / \mathrm{F}$ filters, placed in an $\mathrm{HCl}$ saturated atmosphere, and dried overnight. The activity of filters was measured in a scintillation counter with $2.5 \mathrm{~mL}$ of OptiPhase HiSafe3 scintillation solution (OptiPhase, Van Nuys, California, USA). Dark ${ }^{14} \mathrm{C}$ assimilation was subtracted from PP estimates.

\section{HPLC measurements and pigment analysis}

Photosynthetic and photoprotecting pigments were estimated from triplicate samples $(110-250 \mathrm{~mL})$ collected onto Whatman GF/F filters. Filters were immediately wrapped in aluminum foil and stored at $-80^{\circ} \mathrm{C}$ until processing (within two months of sampling). Pigments were extracted (overnight, at $4^{\circ} \mathrm{C}$, in the dark on a nitrogen-saturated atmosphere) using $90 \%$ (by volume) aqueous acetone and the extracts were cleared by centrifugation at $3000 \mathrm{rpm}$ for $10 \mathrm{~min}$. Pigment extracts were measure by ion pairing reverse-phase HPLC (modified from Mantoura and Llewellyn [1983] and Hurley [1988]) using a Äktabasic chromatograph (Amersham, Buckinghamshire, UK) controlled by the program Unicorn (Amersham, Buckinghamshire, UK). The method employed was described in Laurion et al. (2002). The HPLC system was calibrated with commercially available primary standards provided by the International Agency for ${ }^{14} \mathrm{C}$ Determination or from Sigma (Buchs, Switzerland).

\section{Periphyton assemblage}

Artificial substrates (clear polycarbonate strips of known surface) were suspended at approximately $10 \mathrm{~cm}$ below water surface in each mesocosm. On each sampling date, the periphyton on the substrate was removed by means of a fine brush and divided into aliquots for the different analyses. For the analysis of the periphyton composition the following parameters were considered: algae identification (samples were resuspended and treated as described for phytoplankton), ratio of dead : live algae, chlorophyll $a$ concentra- tion (by reverse-phase HPLC method, as described above), dry mass (DM), and ash-free dry mass (AFDM). Both DM and AFDM are expressed on an areal basis (American Publication Health Association 1998). In addition, the autotrophic index was estimated as the ratio of AFDM:chlorophyll $a$. An AI value higher than 200 indicates high proportion of heterotrophic, nonchlorophyllous organisms or organic detritus (American Publication Health Association 1998, Lowe and Pan 1996).

\section{Statistical analysis}

Prior to each analysis, Kolmogorov-Smirnov tests (with Lilliefors' correction) and Levene median tests were run in order to test data for normality and homoscedasticity. Whenever the data did not conform, the values were transformed (square-root, arcsine square-root, or $\log$ ) as necessary. For all variables, differences among treatments were assayed using repeated-measures analysis of variance (RM ANOVA), with three treatments (control, low dose, and high dose of glyphosate) and four sampling times $(0,1,6$, and 11 d). RM ANOVA analyses were followed by all pairwise multiple comparisons (post hoc testing), using the Holm-Sidak method $(P<0.05)$.

\section{Results \\ Glyphosate dissipation}

The glyphosate concentrations shortly $(1 \mathrm{~h})$ after the herbicide application were $12.65 \pm 2.85 \mathrm{mg} / \mathrm{L}$ (mean \pm $\mathrm{SD})$ in the high-dose treatment, $5.45 \pm 1.01 \mathrm{mg} / \mathrm{L}$ in the low-dose treatment, and below our detection limit $(<0.5$ $\mathrm{mg} / \mathrm{L})$ in the controls. Assuming first-order kinetics, the estimated dissipation rate constants $(k)$ were similar in the two treatments: $k=0.094 \pm 0.017 \mathrm{~d}^{-1}$ for low dose and $k=0.120 \pm 0.027 \mathrm{~d}^{-1}$ for high dose; with half-lives of 5.77 and $7.37 \mathrm{~d}$, respectively (Fig. 1). No significant differences in glyphosate dissipation were observed between doses (paired $t$ test, $P=0.151$ ).

\section{Physical and chemical characteristics of the mesocosms' water}

The initial ionic concentrations in the mesocosms were in general uniform among experimental units. The water for all mesocosms was chemically concentrated (specific conductivity $2.8 \pm 0.1 \mathrm{mS} / \mathrm{cm}$ at $21^{\circ} \mathrm{C}$ ) and alkaline $\left(7750.3 \pm 454.1 \mathrm{mg} \mathrm{CaCO}_{3} / \mathrm{L}\right)$. Ionic composition were characterized by a high concentration of $\mathrm{Na}^{+}$ $(811.6 \pm 37.5 \mathrm{mg} / \mathrm{L})$, and $\mathrm{Cl}^{-}(470.7 \pm 8.4 \mathrm{mg} / \mathrm{L})$ and $\mathrm{HCO}_{3}{ }^{-}(465.5 \pm 39.9 \mathrm{mg} / \mathrm{L})$. Initial mean water temperature and $\mathrm{pH}$ were $17.6 \pm 0.1^{\circ} \mathrm{C}$ and $9.3 \pm 0.2$, respectively. Nutrient concentrations showed high values typical of meso-eutrophic conditions. Mean values of TP and $\mathrm{N}-\mathrm{NH}_{4}{ }^{+}$were $78.9 \pm 1.8 \mu \mathrm{g} / \mathrm{L}$ and $8.9 \pm 1.6$ $\mu \mathrm{g} / \mathrm{L}$, respectively.

During the experiment, water temperature ranged between $17.3^{\circ}$ and $21.8^{\circ} \mathrm{C}, \mathrm{pH}$ ranged between 8.5 and 10.0, and dissolved oxygen ranged between 5.8 and 15 


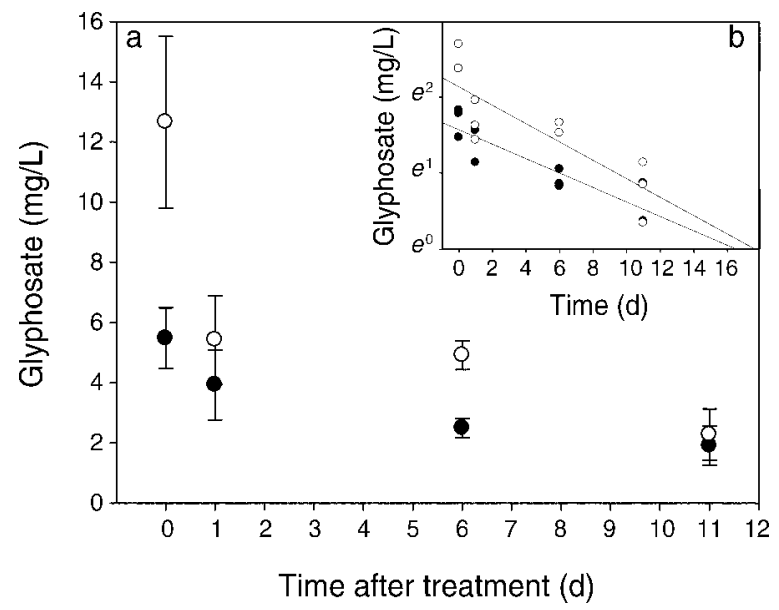

FIG. 1. (a) Dissipation of glyphosate (active ingredient in the herbicide Roundup) from mesocosms' water. Open circles are low doses, and solid circles are high doses. (b) Glyphosate residue fitted to a logarithmic function assuming first-order kinetics. Error bars represent $\pm \mathrm{SD}$.

$\mathrm{mg} / \mathrm{L}$. Conductance averaged $2.8 \pm 0.2 \mathrm{mS} / \mathrm{cm}$ (mean \pm SD), with $\mathrm{Na}^{+}$as the dominant cation $(>97 \%$ of all cations combined) and $\mathrm{Cl}^{-}$and $\mathrm{HCO}_{3}{ }^{-}$as the dominant anions (85\% of all anions). In general, the ionic chemistry did not vary significantly among treatments (RM ANOVA, $P>0.05$ ) although significant differences were observed between dates (Table 1).

The concentration of most nutrients $\left(\mathrm{N}-\mathrm{NH}_{4}{ }^{+}, \mathrm{N}-\right.$ $\mathrm{NO}_{2}{ }^{-}, \mathrm{N}-\mathrm{NO}_{3}{ }^{-}$, and SRP) varied over time, but did not display significant differences among treatments. The important exception being the concentration of total phosphorus (TP), which showed a remarkable increase after the addition of glyphosate to the treated mesocosms. More specifically, significant differences were observed among time and among treatments, as well as the treatment-by-time interaction (Table 1). Values of TP ranged from 58 to $879 \mu \mathrm{g} / \mathrm{L}$ with a mean value of 287 $\mu \mathrm{g} / \mathrm{L}$. Holm-Sidak multiple comparison method showed that the mesocosms treated with both doses of Roundup presented a significant increase in TP concentration from day 0 to day 11 (RM ANOVA, $P<0.005$ ), and that this pattern was not observed in control mesocosms.

Dissolved organic carbon (DOC) and particulate organic carbon (POC) concentrations ranged from 3.19 to $12.41 \mathrm{mg} / \mathrm{L}$ and from 0.3 to $4.1 \mathrm{mg} / \mathrm{L}$, respectively. Total suspended solids (TSS) ranged from 2.6 to $50.4 \mathrm{mg} / \mathrm{L}$. No significant differences among treatments or among times were observed for these variables (RM ANOVA, $P>0.05$ ). (A summary of the physicochemical characteristics of the mesocosms are provided in the Appendix.)

In general, the inherent optical properties (absorption coefficients of particulate and dissolved substances) and the apparent optical properties (PAR vertical attenuation coefficients [Fig. 2a], UVA vertical attenuation coefficients, and turbidity) did not display systematic differences between treatments or dates (RM ANOVA, $P>0.05)$. However, statistically significant differences in the ratio $k_{\mathrm{d}}(490 \mathrm{~nm}) / k_{\mathrm{d}}(550 \mathrm{~nm})$ were observed between times and treatments (Table 1). Mean comparisons revealed that at the end of the experiment significant differences were observed in the ratio $k_{\mathrm{d}}(490$ $\mathrm{nm}) / k_{\mathrm{d}}(550 \mathrm{~nm})$ between high-dose and control treatments (RM ANOVA, $P<0.005$ ), indicating an increase in the attenuation of greenish-blue light as compared to the green wavelengths (Fig. 2c). Such spectral differences in $k_{\mathrm{d}}(\lambda)$ were not observed before glyphosate addition (Fig. 2b; RM ANOVA, $P>0.05$ ).

In addition, we found a significant positive linear relationship between $k_{\mathrm{d}}(490 \mathrm{~nm}) / k_{\mathrm{d}}(550 \mathrm{~nm})$ and $a_{\mathrm{ph}}(490 \mathrm{~nm}) / a_{\mathrm{ph}}(550 \mathrm{~nm})\left(r^{2}=0.71, P=0.004, n=10\right.$; $k_{\mathrm{d}}(490 \mathrm{~nm}) / k_{\mathrm{d}}(550 \mathrm{~nm})=5.17\left[a_{\mathrm{ph}}(490 \mathrm{~nm}) / a_{\mathrm{ph}}(550 \mathrm{~nm})\right]$ $-1.28)$ by the end of the experiment, strongly suggesting that the attenuation at these wavelengths was mostly controlled by the in vivo absorption of phytoplankton.

\section{Effect of Roundup on phytoplankton and periphyton communities}

Phytoplankton abundance ranged from $30 \times 10^{3}$ to $140 \times 10^{3}$ individuals $/ \mathrm{mL}$ (Fig. 3a). Significant differences in micro- and nanophytoplankton abundances

TABLE 1. Summary of the RM ANOVAs for variables that displayed significant differences $(P<0.05)$ due to treatment or the treatment-by-time interaction.

\begin{tabular}{|c|c|c|c|c|c|c|c|c|c|}
\hline \multirow[b]{2}{*}{ Effect } & \multicolumn{3}{|c|}{ Time } & \multicolumn{3}{|c|}{ Treatment } & \multicolumn{3}{|c|}{ Treatment $\times$ time } \\
\hline & $\mathrm{df}$ & $F$ & $P$ & $\mathrm{df}$ & $F$ & $P$ & $\mathrm{df}$ & $F$ & $P$ \\
\hline $\mathrm{TP}$ & 3,18 & 262.324 & $<0.001$ & 2,7 & 50.658 & $<0.001$ & 6,18 & 29.145 & $<0.001$ \\
\hline$K_{\mathrm{d}}(490) / k_{\mathrm{d}}(550)$ & 1,6 & 6.457 & 0.044 & 2,6 & 8.714 & 0.017 & 2,6 & 3.592 & 0.094 \\
\hline Phytoplankton abundance & 3,18 & 3.016 & 0.057 & 2,6 & 6.788 & 0.029 & 6,18 & 9.853 & $<0.001$ \\
\hline $\begin{array}{l}\text { Phytoplankton abundance } \\
\text { (as \% of initial values, \% d 0) }\end{array}$ & 2,12 & 9.796 & 0.003 & 2,6 & 20.602 & 0.002 & 4,12 & 4.876 & 0.014 \\
\hline Picy abundance & 3,18 & 8.187 & 0.001 & 2,6 & 1.739 & 0.254 & 6,18 & 3.689 & 0.014 \\
\hline Periphyton abundance (living/dead) & 3,21 & 12.198 & $<0.001$ & 2,7 & 0.172 & 0.846 & 6,21 & 5.510 & 0.001 \\
\hline $\begin{array}{l}\text { Periphyton abundance (living/dead) } \\
\text { (as \% of initial values, \% } \mathrm{d} \text { 0) }\end{array}$ & 2,14 & 5.281 & 0.020 & 2,7 & 8.469 & 0.020 & 4,14 & 1.410 & 0.281 \\
\hline Primary productivity & 3,18 & 5.915 & 0.005 & 2,6 & 1.919 & 0.227 & 6,18 & 3.265 & 0.024 \\
\hline$($ Zeaxanthin + lutein $) / \operatorname{chl} a$ & 3,21 & 22.240 & $<0.001$ & 2,7 & 3.527 & 0.087 & 6,21 & 4.327 & 0.005 \\
\hline
\end{tabular}




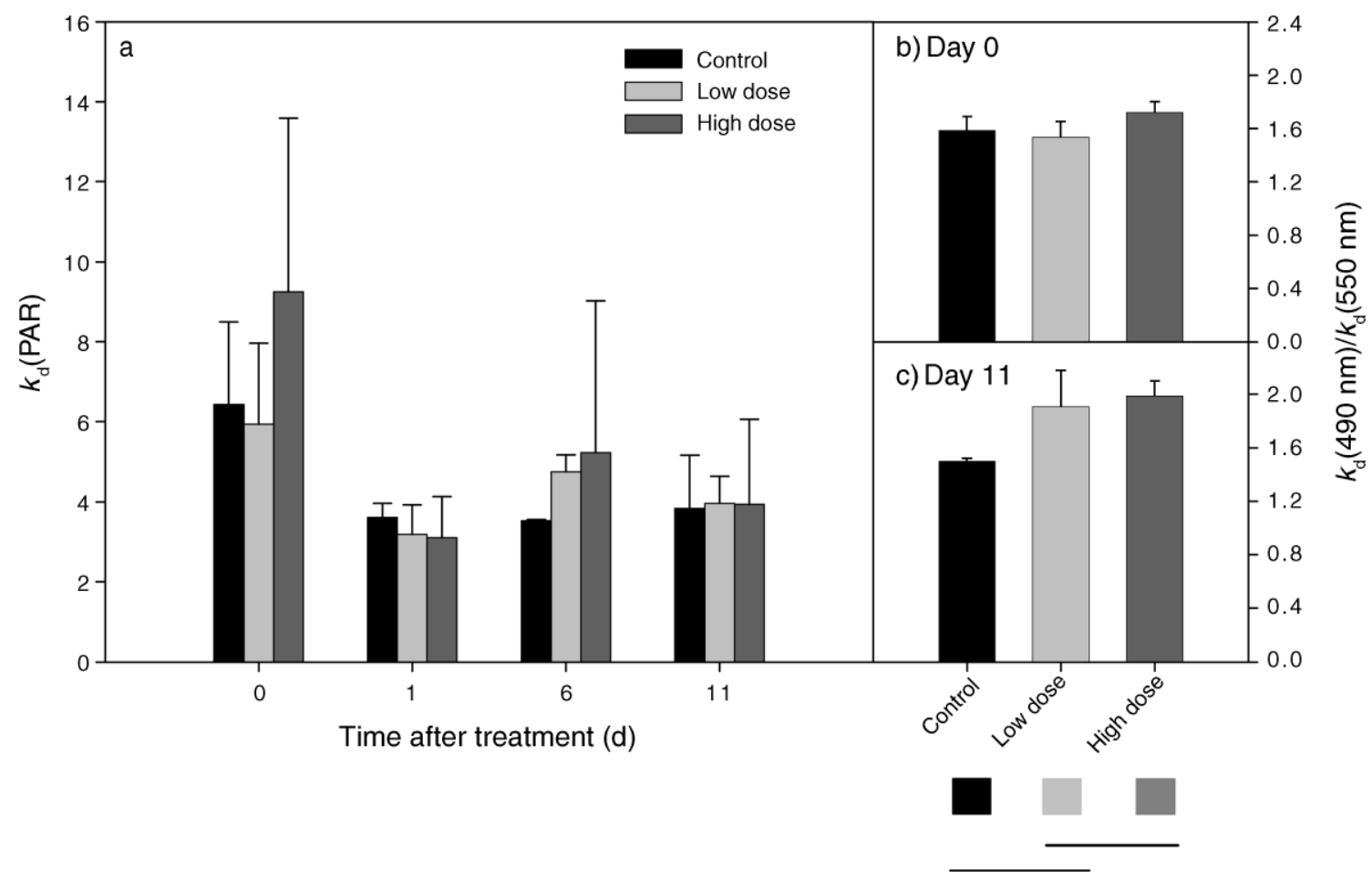

FIG. 2. Downward diffuse attenuation coefficients under control conditions (no Roundup), and at low (6 mg/L) and high (12 $\mathrm{mg} / \mathrm{L})$ doses of glyphosate: (a) $k_{\mathrm{d}}(\mathrm{PAR})$; (b) ratio $k_{\mathrm{d}}(490 \mathrm{~nm}) / k_{\mathrm{d}}(550 \mathrm{~nm})$ on day 0 ; (c) ratio $k_{\mathrm{d}}(490 \mathrm{~nm}) / k_{\mathrm{d}}(550 \mathrm{~nm})$ on day 11 . Statistically significant differences $(P<0.05)$ for day 11 are indicated by the gray scale below panel (c); treatments connected by the same line are not significantly different. Terms: $k_{\mathrm{d}}$, vertical spectral attenuation coefficient $(\lambda)$, under photosynthetically active radiation (PAR) and expressed as a ratio at $490 \mathrm{~nm}$ and $550 \mathrm{~nm}$. Error bars represent $1 \mathrm{SD}$.

$(>3 \mu \mathrm{m})$ were observed among treatments. The interaction between treatments and time was also significant (Table 1). Mean comparisons revealed that the abundance of micro- and nanophytoplankton decreased significantly over time in mesocosms treated with Roundup but not in the controls (Fig. 3a). Due to within-treatment variability, the above differences can be better appreciated by expressing the abundance of phytoplankton as a percentage of the initial values for each mesocosm (Fig. 3b). The micro- and nanophytoplankton abundances standardized to initial values displayed significant differences due to treatments, time, and the treatment-by-time interaction (Table 1). By the end of the experiment, mesocosms treated with both doses of Roundup showed a 2.5-fold decrease in micro- and nanophytoplankton mean abundances (Fig. 3b). No significant differences were observed between treatments when the amount of phytoplankton was expressed as biovolume (RM ANOVA, $P>0.05$ ).

Interestingly, the opposite pattern was displayed by one group of autotrophic picoplankton algae, namely the picocyanobacteria (picy). Picy abundance ranged from $6.02 \times 10^{3}$ to $7.80 \times 10^{6}$ cells $/ \mathrm{mL}$, and significant differences were observed due to time and the time-bytreatment interaction (Table 1). Mean comparisons showed that picy abundance significantly increased after the addition of the Roundup at either dose (RM
ANOVA, $P<0.005$ ), but not in controls (Fig. 3c). By the end of the experiment, mean Picy abundance had increased roughly 40 times in the high-dose treatment as compared to the initial values (RM ANOVA, $P<0.005$; Fig. 3c). On the other hand, the abundance of the remaining picoplanktonic organisms (heterotrophic bacteria and picoplanktonic eukaryotes) did not exhibit significant differences between treatments (RM ANOVA, $P>0.05)$. Mean abundances were $2.12 \times 10^{5} \pm$ $1.75 \times 10^{5}$ cells $/ \mathrm{mL}$ for heterotrophic bacteria and $2.65 \times$ $10^{3} \pm 3.35 \times 10^{3}$ cells $/ \mathrm{mL}$ for picoplanktonic eukaryotes.

The phytoplankton primary production averaged $0.204 \pm 0.182 \mathrm{mg} \mathrm{C} \cdot \mathrm{L}^{-1} \cdot \mathrm{h}^{-1}$, and ranged from 0.03 to $1.02 \mathrm{mg} \mathrm{C} \cdot \mathrm{L}^{-1} \cdot \mathrm{h}^{-1}$ ). PP did not show significant differences among treatments, but the differences due to the interaction between treatment and time were significant (Table 1, Fig. 3d). Mean comparisons showed that the mesocosms treated with higher dose experienced a twofold increase in PP from day 0 to day 11 (RM ANOVA, $P<0.005)$. A similar, but nonsignificant, trend was observed in the lower dose treatment (RM ANOVA, $P>0.05)$. This pattern was not observed in control mesocosms (RM ANOVA, $P>0.05$ ).

Regarding the periphyton assemblage, the values of chlorophyll $a$ and AFDM averaged $4.98 \pm 4.67 \mu \mathrm{g} / \mathrm{cm}^{2}$ and $2963 \pm 2929 \mu \mathrm{g} / \mathrm{cm}^{2}$, respectively. No significant 

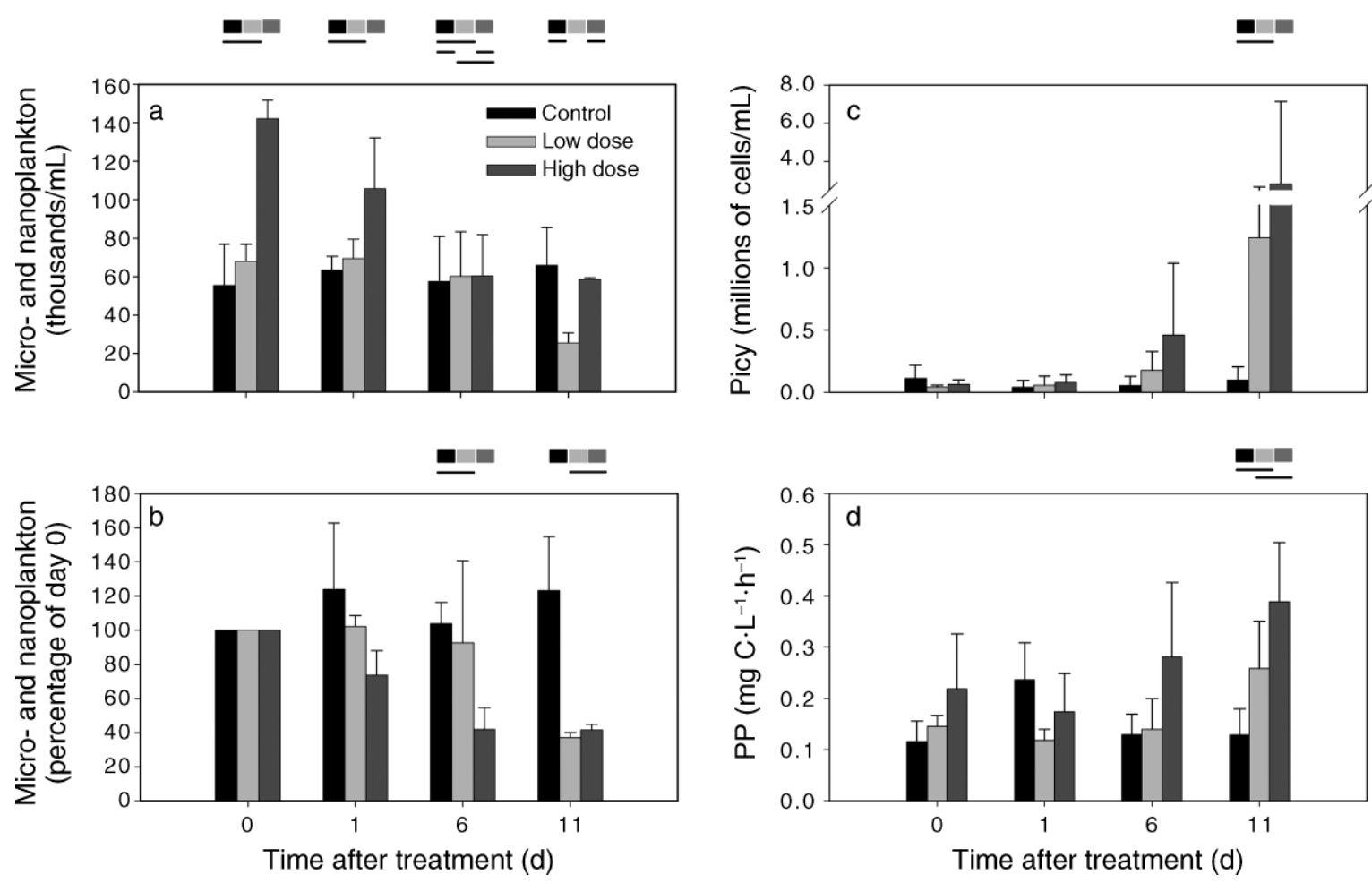

FIG. 3. (a) Total micro- and nanophytoplankton abundance; (b) algal abundance standardized to initial values on day 0; (c) picocyanobacteria (picy) abundance (notice the break in the $y$-axis); and (d) phytoplankton primary production (PP). Statistically significant differences $(P<0.05)$ are indicated by the gray scale above the panels; treatments connected by the same line are not significantly different. Error bars represent $1 \mathrm{SD}$.

differences among treatment were detected for these estimates of biomass. The periphyton assemblage was dominated by Bacillariophyceae (77\%), followed by Cyanobacteria $(21.2 \%)$ and Chlorophyceae $(0.6 \%)$. The variability in total periphyton algal abundance (dead + live organisms: 484878 and 5861686 individuals $/ \mathrm{cm}^{2}$ ) could not be related to treatments and dates. However, the proportion living/dead organisms showed significant differences among time and in the treatment-by-time interaction (Table 1). The living/dead proportion was also expressed as percentage of the initial values to account for the initial differences among replicates (Fig. 4a). By doing so, differences among time and among treatments could be observed (Table 1). Mean comparisons showed that living/dead proportion (as a percentage of initial values) showed significant differences between control and treated mesocosms for both doses (RM ANOVA, $P<0.005$ ). By the end of the experiment, the proportion of total living individuals in the mesocosms treated with the Roundup was about one-third of that observed in the control mesocosms, and the proportion was even smaller (approximately one-fifth) for the Bacillariophyceae. Paralleling the trends observed in the phytoplankton assemblage, the periphytic cyanobacteria (particularly Cyanothece spp.) appeared to increase after the addition of the herbicide (Fig. 4b), but in this case, the differences among treatments were not statistically significant. Similarly, the autotrophic index (AI), tended to increase in the treated mesocosms, but again in this case the differences between treatments were not significant (Fig. 4c).

\section{Effect of Roundup on phytoplanktonic pigment composition}

Overall, we were able to detect the presence of the following pigments: $\operatorname{chl} a, \operatorname{chl} b, \operatorname{chl} c_{1}+c_{2}$ (which could not be distinguished by our method), neoxanthin, fucoxanthin, diadinoxanthin, astaxanthin, alloxanthin, mixoxanthophyll, zeaxanthin + lutein (which could not distinguished by our method), echinenone, and $\beta$ carotene. The variations in pigment concentration standardized to chl $a$ are summarized in Fig. 5. The concentrations of some pigments were significantly affected by the addition of Roundup. An increase in zeaxanthin + lutein relative to chl $a$ was observed in the treated mesocosms (Fig. 5e). Although RM ANOVA analysis did not show significant differences between treatment, the treatment-by-time interaction was significant $(P<0.001$; Table 1$)$, and by the end of the experiment the concentration of zeaxanthin + lutein in the treated mesocosms was significantly higher than the initial values (RM ANOVA, $P<0.005)$. Such a pattern was not observed in the controls (RM ANOVA, $P>$ 0.05). A significant linear relationship was obtained 
between zeaxanthin + lutein and picy abundance $\left(r^{2}=\right.$ $0.51, P=0.001, n=32 ; \log [$ picy $]=1.02 \log [$ zeaxanthin + lutein] +4.37 ; Fig. 6a). In addition, a significant linear relationship was obtained between $a_{\mathrm{ph}}(490 \mathrm{~nm}) / a_{\mathrm{ph}}(550$ $\mathrm{nm})$ and picy abundance $\left(r^{2}=0.43, P=0.001, n=33\right.$; $\log [$ picy $]=0.27\left[a_{\mathrm{ph}}(490 \mathrm{~nm}) / a_{\mathrm{ph}}(550 \mathrm{~nm})\right]+3.98$; Fig. $6 \mathrm{~b})$, as well as between $k_{\mathrm{d}}(490 \mathrm{~nm}) / k_{\mathrm{d}}(550 \mathrm{~nm})$ and zeaxanthin + lutein $\left(r^{2}=0.70, P=0.002, n=10\right.$; $\log [$ zeaxanthin + lutein $]=2.01\left[k_{\mathrm{d}}(490 \mathrm{~nm}) / k_{\mathrm{d}}(550 \mathrm{~nm})\right]-$ 2.74; Fig. 6c).

\section{Discussion}

Glyphosate half-lives $(\sim 6-7 \mathrm{~d})$ was longer than most values reported in the literature (half-lives $<4 \mathrm{~d}$ ) for streams (Newton et al. 1984, Feng et al. 1990) and ponds (Goldsborough and Beck 1989). To our knowledge, only one study had reported higher glyphosate half-lives (11.2 d) in water of boreal forest ponds (Goldsborough and Brown 1993). Laboratory and field studies suggested that the main mechanism of glyphosate removal from water is adsorption to suspended particulates followed by subsequent sedimentation and/or biodegradation (Goldsborough and Beck 1989, Feng et al. 1990, Zaranyika and Nyandoro 1993). Adsorption of glyphosate increases with the amount of suspended solids, decreases with soil $\mathrm{pH}$, inorganic phosphorus content, and cation concentration, and is poorly correlated with textural parameters (Sprankle et al. 1975a, b, Hance 1976, Nomura and Hilton 1977, Rueppel et al. 1977, Glass 1987, Goldsborough and Beck 1989). The relatively long half-live obtained in this study may be partly related to the high cation concentrations prevailing in our mesocosms. The physicochemical conditions observed in our mesocosms were similar to those reported for shallow lakes in the surrounding area (Izaguirre and Vinocur 1994), whose waters are alkaline, dominated by sodium-bicarbonate, and characterized by high trophic degree (Ringuelet et al. 1968, Ringuelet 1972).

The duration of our experiment was decided a priori on the basis of published decay rates of glyphosate, which indicated that the glyphosate concentration would drop below detection limits within $10 \mathrm{~d}$. However due to the longer half life, observed in our experiment, measurable concentrations of glyphosate were present by the end of our study. The assayed concentrations of Roundup significantly affected the structure and functioning of our experimental systems. A major change in water chemistry was the significant increase in total phosphorus concentration. The commercial formulation, Roundup, contains glyphosate, water, and POEA (Folmar et al. 1979, Relyea 2005a,b). POEA is a complex mixture of fat from fatty tissues of cattle or sheep, whose precise formulation is kept as a secret by Monsanto, but which is not supposed to contain phosphorus. On the other hand, phosphorus contributes $14 \%$ to the molecular weight of glyphosate. Thus, the nominal concentrations of glyphosate applied to our
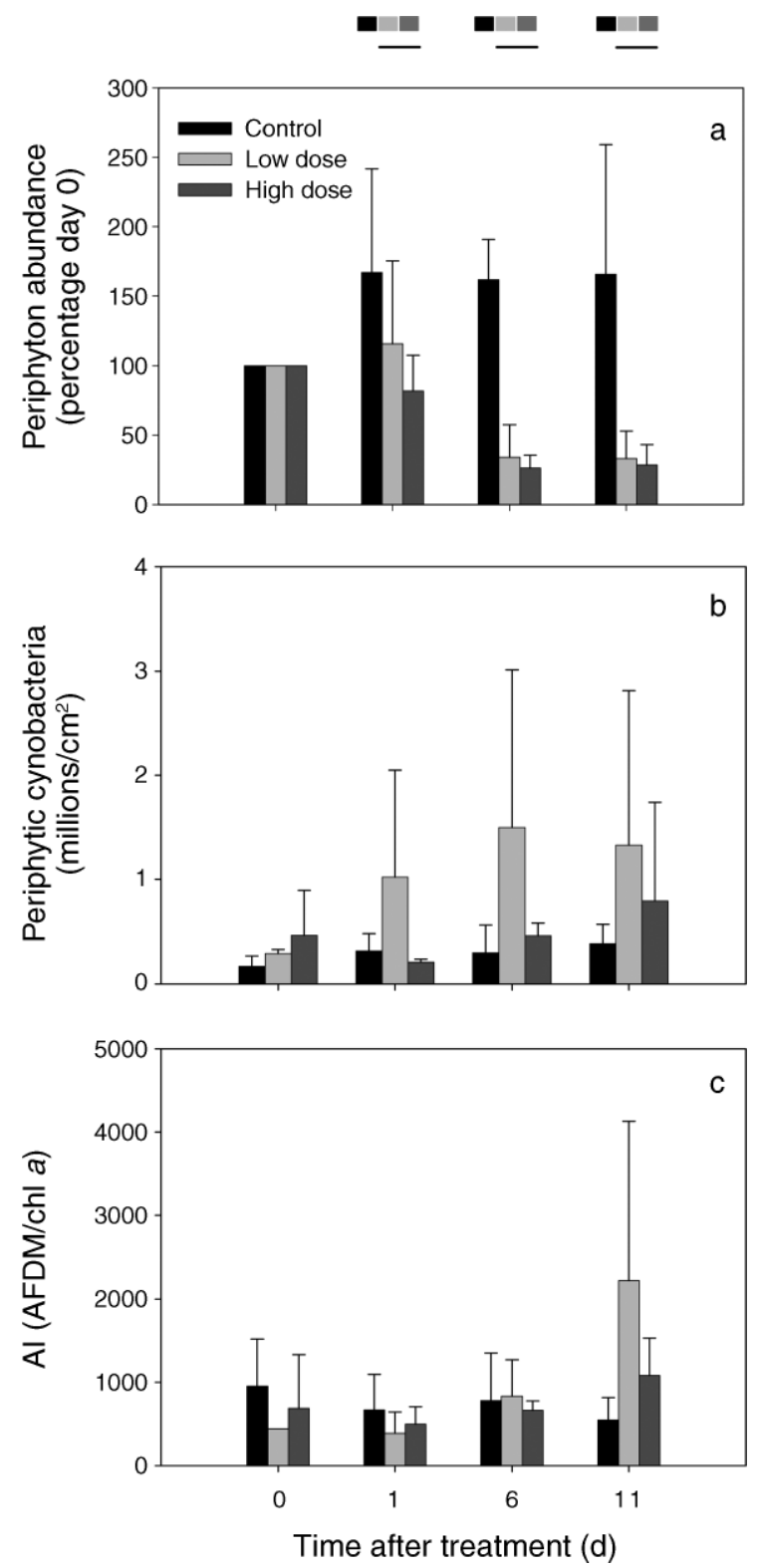

FIG. 4. (a) Ratio of living/dead periphyton as percentage of initial values on day 0 ; (b) total periphytic cyanobacteria abundance; and (c) autotrophic index (AI), the ratio of ash-free dry mass of autotrophs to chlorophyll $a$. Significant differences $(P<0.05)$ are indicated by the gray scale code above the graph; treatments connected by the same line are not significantly different.

mesocosms, 6 and $12 \mathrm{mg} / \mathrm{L}$, contributed 840 and 1680 $\mu \mathrm{g} / \mathrm{L}$ of phosphorus. These concentrations are higher than those actually measured immediately after the addition of Roundup. For the remaining sampling dates, the amount of TP measured in our mesocosms was always similar or lower than the amount predicted by the sum of the initial TP concentration plus the phosphorus supplied by the measured concentrations of glyphosate. In other words, the measured amounts of 

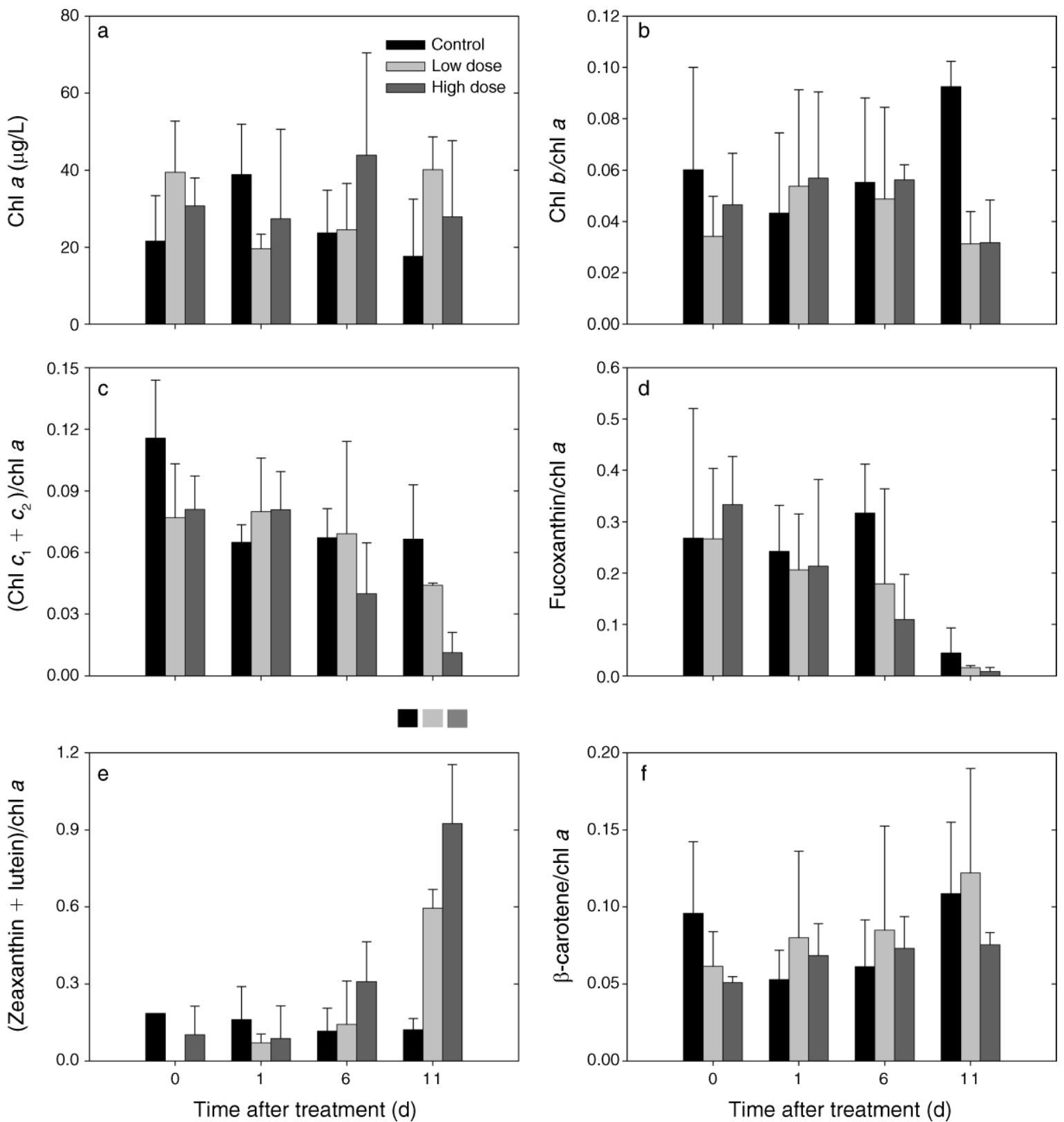

FIG. 5. Main algal accessory pigment concentrations relative to chlorophyll $a$. Coding of significant differences is as in Fig. 4.

glyphosate always sufficed to explain the increase in TP observed in the treated mesocosms.

Phosphorus is one of the key factors influencing algal assemblages, thus the observed changes in phytoplankton and periphyton composition could have been mediated by an indirect effect (i.e., the increase in TP), rather than by the direct toxicological effect of Roundup. However two pieces of evidence are contrary to the first alternative, and indirectly provide support for the toxicological interpretation. First as mentioned above, the excess of TP may be completely explained by the presence of glyphosate in solution, and as such unavailable for algae growth, at least by the time of sample collection. Second, several studies have shown that large algae benefit more that small algae upon phosphorus enrichment (Stockner 1988, Masson et al. 2000). In contrast, we observed a decrease in the abundance of the largest fractions and a marked increase of picy abundance in response to glyphosate addition. Interestingly, the observed changes in phytoplankton assemblage fractions did not translate into significant changes of biovolume or $\operatorname{chl} a$.

On the other hand, many of the effects observed in our study are consistent with previous works using glyphosate formulations without additives. For instance, the observed negative effect on several large size 
phytoplankton species is consistent with the results from single species toxicity tests (e.g., Gresshoff 1979, Sáenz et al. 1997) and mesocosm-scale experiments (Kallqvist et al. 1994). In addition, the observed increases in primary production are consistent with the results obtained by Schaffer and Sebetich (2004), which used the commercial product Rodeo, which lacks additives.

There is little available information comparing the effects of glyphosate alone and those of commercial formulations on phytoplankton and periphyton species. Sáenz et al. (1997) founded that surfactant increased the toxicity of glyphosate on periphyton assemblages in experiments conducted with both technical grade glyphosate and Ron-do (a product including a different surfactant, i.e., not POEA). Cedergreen and Streibig (2005) reported that Roundup was roughly four times more toxic to the aquatic macrophyte Lemna minor and the green alga Pseudokirchneriella subcapitata than glyphosate alone.

One of the most remarkable results of our experiments was the roughly 40 -fold increase in Picy abundance. To our knowledge, this is the first report that Roundup stimulates picocyanobacteria in freshwater systems. Cyanobacteria are known to be resistant to glyphosate by either one of two mechanisms: the overproduction of EPSP synthase, or the production of a glyphosatetolerant enzyme (Powell et al. 1991, 1992).

There is a paucity of investigations on the effect of glyphosate on periphytic communities (Hoagland et al. 1996), and the few studies that have been published used different experimental designs (Goldsborough and Brown 1988, Austin et al. 1991). In our study, the effects of Roundup on periphyton mirrored those observed in the phytoplankton assemblage. Particularly, the proportion of cyanobacteria increased at the expense of diatoms. The trends in both phytoplankton and periphyton support the general perception that cyanobacteria are particularly resistant to extreme environments, including herbicide stressed habitats (Powell et al. 1991, 1992).

The possibility that Roundup could stimulate nuisance algae warns against its indiscriminate use. In particular, the development of cyanobacteria blooms in freshwaters have been recognized as significant events that may adversely affect water quality and impact human and animal health (Carmichael 1994, Bell and Codd 1996).

On a methodological note, the assessment of agrochemical impacts on natural aquatic communities is still incipient (Pratt et al. 1997, Readman et al. 2004). Readman et al. (2004) demonstrated the applicability and sensitivity of high resolution pigment analyses to quantitatively investigate toxic effects on natural phytoplanktonic communities. We have used a relatively large variety of environmental parameters and techniques to assess the potential effects of herbicide contamination of aquatic environments. One important goal was to identify simple methods that could provide
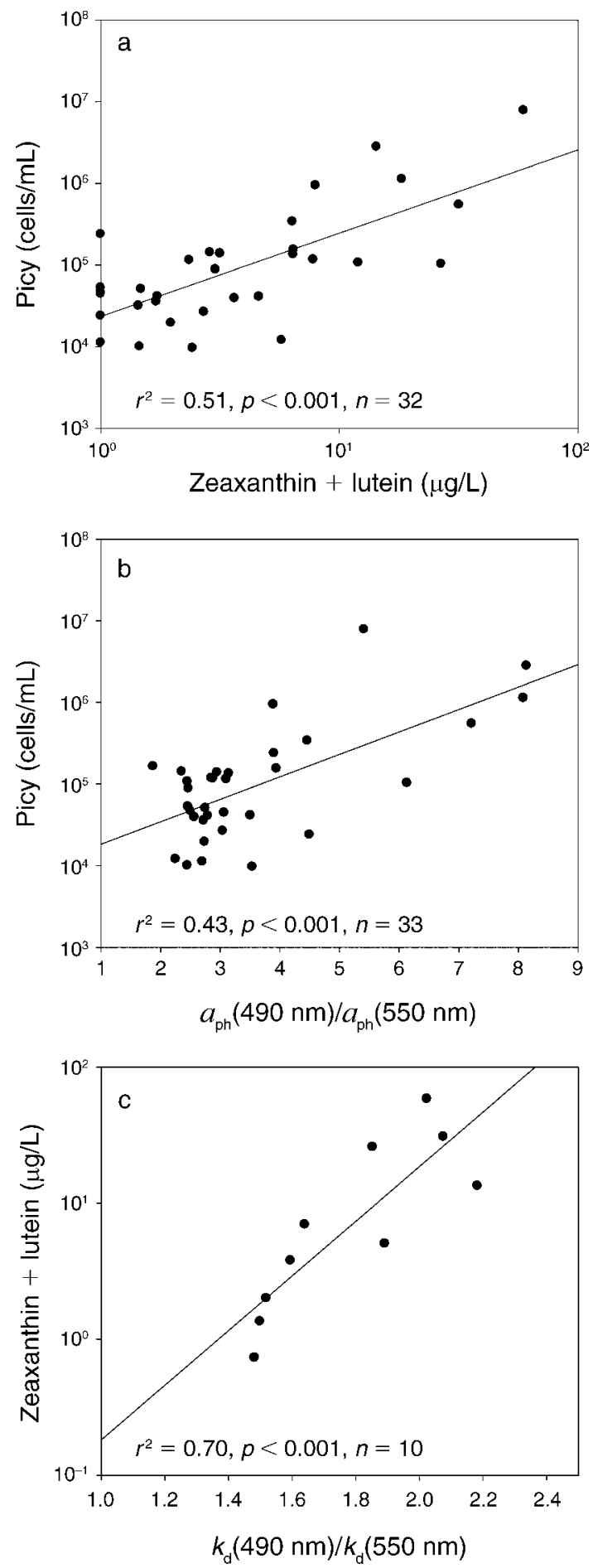

FIG. 6. (a) Positive linear relationship obtained between picy cell abundance and zeaxanthin + lutein concentration; (b) positive linear relationship obtained between picy abundance and $a_{\mathrm{ph}}(490) / a_{\mathrm{ph}}(550)$; (c) positive linear relationship obtained between zeaxanthin + lutein concentration and $k_{\mathrm{d}}(490) / k_{\mathrm{d}}(550)$. 
reliable assessments of changes in the functioning of ecosystems (see Pratt et al. 1997).

The inherent and apparent optical properties of water differed significantly between treated and untreated mesocosms. In turn, a great deal of the differences in spectral attenuation (e.g., the $\left.k_{\mathrm{d}}(490 \mathrm{~nm}) / k_{\mathrm{d}}(550 \mathrm{~nm})\right)$ could be explained by differences in the pigment composition of phytoplankton, particularly the increase in zeaxanthin + lutein, which paralleled the increase in picocyanobacteria. This correlation strongly suggests that the main pigment was zeaxanthin and that little, if any lutein was actually present. Our ability to detect changes in the phytoplankton assemblage through the analysis of pigment composition and the optical properties of the water is certainly encouraging, as both methods demand only a fraction of the time and resources required for taxonomic identifications.

\section{Conclusions}

Agriculture has always impacted natural ecosystems to different extents. Within the last decades, pesticides have emerged as novel stressors with potential for directly or indirectly affecting non-target microbial aquatic communities. The worldwide adoption of glyphosate based herbicides, such as the commercial formulation Roundup, has been fueled by the development of GR crops. An open controversy exists regarding the magnitude of the environmental effects that may follow the recent pervasive changes in agricultural practices. In contrast to the manufacturers' claims on the environmental safety of glyphosate, several studies have demonstrated that glyphosate alone or in combination with the additives used in commercial formulations may be damaging to aquatic biota. Our study builds upon the wealth of previous works, by demonstrating that glyphosate may affect phytoplankton and periphyton community composition. To the best of our knowledge, this is the first time that glyphosate have been shown to stimulate the development of picocyanobacteria in experimental mesocosms. Such increase occurred at the expense of larger algae, and has important potential implications for higher trophic levels (a possibility that we are currently pursuing). It is therefore not only conceivable, but also quite likely that current agricultural practices, which heavily relies upon continual additions of glyphosate at regional scales may alter the structure and function of many natural aquatic environments.

\section{ACKNOWLEDGMENTS}

We thank Alicia Ronco for her advice on glyphosate analysis and Isidoro Sorokin from Gleba S. A. for his gift of technical-grade glyphosate. This work was supported by CONICET PIP 5614 and Universidad Nacional de General San Martín grant S-05/19.

\section{Literature Cited}

Ali, A., and R. A. Fletcher. 1978. Phytotoxic action of glyphosate and amitrole on corn seedlings. Canadian Journal of Botany 56:2196-2202.
American Publication Health Association. 1998. Standard methods for the examination of water and wastewater. 20th edition. American Publication Health Association, Washington, D.C., USA.

Austin, A. P., G. E. Harris, and W. P. Lucey. 1991. Impact of an organophosphate herbicide $\left(\right.$ glyphosate $^{\circledR}$ ) on periphyton communities developed in experimental streams. Bulletin of Environment Contamination and Toxicology 47:29-35.

Bell, S. G., and G. A. Codd. 1996. Detection analysis and risk assessment of cyanobacterial toxins. Pages 109-122 in R. E. Hester and R. M. Harrison, editors. Agricultural chemicals and the environment. Issues in environmental science and technology no. 5. Royal Society of Chemistry, Cambridge, UK.

Bowmer, K. H. 1982. Adsorption characteristics of seston in water: implications for the use of aquatic herbicides. Australian Journal of Marine and Freshwater Research 33: 443-458.

Bricaud, A., and D. Stramski. 1990. Spectral absorption of living phytoplankton and non algal biogenus matter: a comparison between the Peru upwelling area and the Sargasso Sea. Limnology and Oceanography 35:562-582.

Campbell, W. F., J. O. Evans, and S. C. Reed. 1976. Effects of glyphosate on chloroplast ultrastructure of quackgrass mesophyll cells. Weed Science 24:22-25.

Carmichael, W. W. 1994. The toxins of Cyanobacteria. Scientific American 270:78-86.

Caron, D. A. 1983. Technique for enumeration of heterotrophic and phototrophic nano-phytoplankton, using epifluorescence microscopy, and comparison with other procedures. Applied Environmental Microbiology 46:491-498.

Cedergreen, N., and J. C. Streibig. 2005. The toxicity of herbicides to non-target aquatic plants and algae: assessment of predictive factors and hazard. Pest Management Science 61:1152-1160.

Duke, S. O., S. R. Baerson, and A. M. Rimando. 2003. Herbicides: glyphosate. In J. R. Plimmer, D. W. Gammon, and N. N. Ragsdale, editors. Encyclopedia of agrochemicals. John Wiley and Sons, New York, New York, USA [doi:10. 1002/047126363X.agr.119].

Feng, J. C., D. G. Thompson, and P. Reynolds. 1990. Fate of glyphosate in a Canadian forest watershed. 1. Aquatic residues and off-target deposit assessment. Journal of Agricultural and Food Chemistry 38:1110-1118.

Folmar, L. C., H. O. Sanders, and A. M. Julin. 1979. Toxicity of the herbicide glyphosate and several of its formulations to fish and aquatic invertebrates. Archives of Environment Contamination and Toxicology 8:269-278.

Franz, J. E., M. K. Mao, and J. A. Sikorski. 1997. Glyphosate. A unique global herbicide. American Chemistry Society, ASC Monographs 189:1-600.

Gardner, S. C., C. E. Grue, J. M. Grassley, L. A. Lenz, J. M. Lindenauer, and M. E. Seeley. 1997. Single species algal (Ankistrodesmus) toxicity tests with Rodeo ${ }^{\circledR}$ and Garlon ${ }^{\circledR} 3 \mathrm{a}$. Bulletin of Environment Contamination and Toxicology 59: 492-499.

Giesy, J. P., S. Dobson, and K. R. Solomon. 2000. Ecotoxicological risk assessment for Roundup ${ }^{\circledR}$ herbicide. Review of Contamination and Toxicology 167:35-120.

Glass, R. L. 1987. Phosphate adsorption by soils and clay minerals. Journal of Agricultural Food Chemistry 35:497500 .

Goldsborough, L. G., and A. E. Beck. 1989. Rapid dissipation of glyphosate in small forest ponds. Archives of Environment Contamination and Toxicology 18:537-544.

Goldsborough, L. G., and D. J. Brown. 1988. Effect of glyphosate (Roundup ${ }^{\circledR}$ formulation) on periphytic algal photosynthesis. Bulletin of Environment Contamination and Toxicology 41:253-260.

Goldsborough, L. G., and D. J. Brown. 1989. Rapid dissipation of glyphosate and aminomethylphosphonic acid in water and 
sediments of boreal forest ponds. Environmental Toxicology and Chemistry 12:1139-1147.

Goldsborough, L. G., and D. J. Brown. 1993. Dissipation of glyphosate and aminomethylphosphonic acid in water and sediments of boreal forest ponds. Environmental Toxicology and Chemistry 12:1139-1147.

Gresshoff, P. M. 1979. Growth inhibition by glyphosate and reversal of its action by phenylalanine and tyrosine. Australian Journal of Plant Physiology 6:177-185.

Gustavson, K., F. Mohlenberg, and L. Schlüter. 2003. Effects of exposure duration of herbicides on natural stream periphyton communities and recovery. Archives of Environment Contamination and Toxicology 45:48-98.

Hance, R. 1976. Adsorption of glyphosate by soils. Pesticide Science 7:363-366.

Hartman, W. A., and D. B. Martin. 1985. Effects of four agricultural pesticides on Daphnia pulex, Lemna minor, and Potamogeton pectinatus. Bulletin of Environmental Contamination and Toxicology 35:646-651.

Hawley, G. R. W., and B. Whitton. 1991. Survey of algal picoplankton from lakes in five continents. Verhandlungen Internationale Vereinigung Limnology 24:1220-1222.

Hernando, F., M. Royuela, A. Muñoz-Rueda, and C. Gonzalez-Murua. 1989. Effect of glyphosate on the greening process and photosynthetic metabolism in Chlorella pyrenoidosa. Journal of Plant Physiology 134:26-31.

Hoagland, K. D., J. P. Carder, and R. L. Spawn. 1996. Effects of organic toxic substances. Pages 469-496 in R. J. Stevenson, M. L. Bothwell, and R. L. Lowe, editors. Algal ecology. Freshwater benthic ecosystems. Academic Press, San Diego, California, USA.

Hurley, J. P. 1988. Analysis of aquatic pigments by high performance liquid chromatography. Journal of Analytical Purificación 3:12-16.

Instituto Nacional de Tecnologías Agropecuarias. 2003. La sustentabilidad de la producción agropecuaria Argentina. 〈www.inta.gov.ar〉

Izaguirre, I., and A. Vinocur. 1994. Typology of shallow lakes of the Saldo River basin (Argentina), based on phytoplankton communities. Hydrobiologia 277:49-62.

James, C. 2003. Global status of commercialized transgenic crops. International Service for the Acquisition of Agribiotech Applications 30.

Kallqvist, T., M. I. Abdel-Hamid, and D. Berge. 1994. Effects of agricultural pesticides on freshwater plankton communities in enclosures. Norwegian Journal of Agricultural Sciences 13(Supplement):133-152.

Kirk, J. T. O. 1994. Light and photosynthesis in aquatic ecosystems. Cambridge University Press, Cambridge, UK.

Kishino, M., C. R. Booth, and N. Okami. 1984. Underwater radiant energy absorbed by phytoplankton, detritus, dissolved organic matter, and pure water. Limnology and Oceanography 22:340-349.

Kreutzweiser, D. P., P. D. Kingsbury, and J. C. Feng. 1989. Drift response of stream invertebrates to aerial applications of glyphosate. Bulletin of Environmental Contamination and Toxicology 42:331-338.

Lapitz, R., G. Evia, and E. Gudynas. 2004. Soja y Carne en el Mercosur. Coscoroba, Montevideo, Uruguay.

Laurion, I., A. Lami, and R. Sommaruga. 2002. Distribution of mycosporine-like amino acids and photoprotective carotenoids among freshwater phytoplankton assemblages. Aquatic Microbial Ecology 26:283-294.

Lowe, R. L., and Y. Pan. 1996. Benthic algal communities as biological monitors. Pages 705-740 in R. J. Stevenson, M. L. Bothwell, and R. L. Lowe, editors. Algal ecology. Freshwater benthic ecosystems. Academic Press, San Diego, California, USA.

Mantoura, R. F. C., and C. A. Llewellyn. 1983. The rapid determination of algal chlorophyll and carotenoid pigments and their breakdown products in natural waters by reverse- phase high-performance liquid chromatography. Analytica Chimica Acta 151:297-314.

Masson, S., B. Pinel-Allow, and B. H. Smith. 2000. Total phosphorus-chlorophyll $a$ size fraction relationships in southern Québec lakes. Limnology and Oceanography 45: 732-740.

Miles, C. J., L. R. Wallace, and H. A. Moye. 1986. Determination of glyphosate herbicide and (aminomethyl) phosphonic acid in natural waters by liquid chromatography using pre-column fluorogenic labeling with 9-fluorenylmethyl chloroformate. Journal of the Association of Official Analytical Chemists 69:458-461.

Mitchell, B. G., and D. A. Kiefer. 1988. Variability in pigment specific particulate fluorescence and absorption spectra in the northeastern Pacific Ocean. Deep-Sea Research 35:665-689.

Mitchell, D. G., P. M. Chapman, and T. J. Longs. 1987. Acute toxicity of Roundup and Rodeo herbicides to rainbow trout, chinook, and coho salmon. Bulletin of Environmental Contamination and Toxicology 39:1028-1035.

Newton, M., K. M. Howard, B. R. Kelpsas, R. Danhaus, C. M. Lottman, and S. Dubelman. 1984. Fate of glyphosate in an Oregon forest ecosystem. Journal of Agricultural and Food Chemistry 32:1144-1151.

Nomura, N. S., and H. W. Hilton. 1977. The adsorption and degradation of glyphosate in five Hawaiian sugarcane soils. Weed Research 17:113-121.

Pechlaner, R. 2002. Glyphosate in herbicides: an overlooked threat to microbial bottom-up processes in freshwater systems. Verhandlungen Internationale Vereinigung Limnology 28:1831-1835.

Porter, K. C., and Y. S. Feig. 1980. The use of DAPI for identifying and counting aquatic microflora. Limnology and Oceanography 25:943-948.

Powell, H. A., N. W. Kerby, and P. Rowell. 1991. Natural tolerance of cyanobacteria to the herbicide glyphosate. New Phytology 119:421-426.

Powell, H. A., N. W. Kerby, P. Rowell, D. M. Mousdale, and J. R. Coggins. 1992. Purification and properties of a glyphosate-tolerant 5-enolpyruvylshikimate-3-phosphate synthase from the cyanobacterium Anabaena variabilis. Planta 188:484-490.

Pratt, J. R., A. E. Melendez, R. Barreiro, and N. J. Bowers. 1997. Predicting the ecological effects of herbicides. Ecological Applications 7:1117-1124.

Rankin, L. M., P. D. Franzmann, T. A. McMeekin, and H. R. Burton. 1997. Seasonal distribution of picocyanobacteria in Ace Lake, a marine-derived Antarctic lake. Pages 178-184 in B. Battaglia, J. Valencia, and D. W. H. Walton, editors. Antarctic communities, species, structure and survival. Cambridge University Press, Cambridge, UK.

Readman, J. W., R. A. Devilla, G. Tarran, C. A. Llewellyn, T. W. Fileman, A. Easton, P. H. Burkill, and R. F. C. Mantoura. 2004. Flow cytometry and pigment analyses as tools to investigate the toxicity of herbicides to natural phytoplankton communities. Marine Environmental Research 58:353-358.

Relyea, R. A. 2004. Growth and survival of five amphibian species exposed to combinations of pesticides. Environmental Toxicology and Chemistry 23:1737-1742.

Relyea, R. A. 2005a. The impact of insecticides and herbicides on the biodiversity and productivity of aquatic communities. Ecological Applications 15:618-627.

Relyea, R. A. 2005b. The lethal impact of Roundup on aquatic and terrestrial amphibians. Ecological Applications 15:11181124.

Relyea, R. A., N. M. Schoeppner, and J. T. Hoverman. 2005. Pesticides and amphibians: the importance of assemblage context. Ecological Applications 5:1125-1134.

Ringuelet, R. 1972. Tipología de las lagunas de la Provincia de Buenos Aires. La Limnología Regional y los Tipos Lagunares. Physis 31:55-76. 
Ringuelet, R., A. Salibián, E. Claverie, and S. Ilhero. 1968. Limnología química de las Lagunas Pampásicas. Physis 17: 201-221.

Rohr, J. R., and P. W. Crumrine. 2005. Effects of an herbicide and an insecticide on pond community structure and processes. Ecological Applications 15:1135-1147.

Roy, D. N., S. K. Konar, S. Banerjee, D. A. Charles, D. G. Thompson, and R. Prasad. 1989. Uptake and persistence of the herbicide glyphosate in fruit of wild blueberry and red raspberry. Canadian Journal of Forest Research 19:842-847.

Rueppel, M. L., B. B. Brightwell, J. Schaefer, and J. T. Marvel. 1977. Metabolism and degradation of glyphosate in soil and water. Journal of Agricultural and Food Chemistry 25:517528.

Sáenz, M. E., W. D. Di Marzio, J. L. Alberdi, and M. del Carmen Tortorelli. 1997. Effects of technical grade and a commercial formulation of glyphosate on algal population growth. Bulletin of Environmental Contamination and Toxicology 59:638-644.

Schaffer, J. D., and M. J. Sebetich. 2004. Effects of aquatic herbicides on primary productivity of phytoplankton in the laboratory. Bulletin of Environmental Contamination and Toxicology 72:1032-1037.

Servizi, J. A., R. W. Gordon, and D. W. Martens. 1987. Acute toxicity of Garlon 4 and Roundup herbicides to salmon, Daphnia, and trout. Bulletin of Environmental Contamination and Toxicology 39:15-22.

SETAC-RESOLVE. 1992. Workshop on aquatic microcosm for ecological assessment of pesticides. The SETAC Foundation for Environmental Education and Resolve (a program of the World Wildlife Fund), Wintergreen, Virginia, USA.

Sprankle, P. W., F. Meggitt, and D. Penner. 1975a. Rapid inactivation of glyphosate in the soil. Weed Science 23:224228.

Sprankle, P. W., F. Meggitt, and D. Penner. 1975b. Adsorption, mobility, and microbial degradation of glyphosate in the soil. Weed Science 23:229-234.

Steeman-Nielsen, E. 1952. The use of radioactive carbon $\left({ }^{14} \mathrm{C}\right)$ for measuring organic production in the sea. Journal du Conseil 18:117-140.
Stockner, J. G. 1988. Phototrophic picoplankton: An overview from marine and freshwater ecosystems. Limnology and Oceanography 33:765-775.

Streit, B. 1992. Bioaccumulation processes in ecosystems. Experientia 48:955-970.

Sun, J., and D. Liu. 2003. Geometric models for calculating cell biovolume and surface area for phytoplankton. Journal of Plankton Research 25(11):1331-1346.

Thompson, D. G., B. F. Wojtaszek, B. Staznik, D. T. Chartrand, and G. R. Stephenson. 2004. Chemical and biomonitoring to assess potential acute effects of Visiont herbicide on native amphibian larvae in forest wetlands. Environmental Contamination and Toxicology 23:843-849.

Trüper, H. G., and C. S. Yentsch. 1967. Use of glass fiber filters for the rapid preparation of in vivo absorption spectra of photosynthetic bacteria. Journal of Bacteria 94:1255-1256.

U.S. Environmental Protection Agency. 1993. Registration eligibility decision (RED): glyphosate. Office of Pesticide Programs. U.S. Environmental Protection Agency, Special Review and Registration Division, Washington, D.C., USA.

Utermöhl, H. 1958. Zur vervollkommnung der quantitativen Phytoplankton Methodik. Mitteilungen Internationale Vereinigung für Limnologie 9:1-38.

Venrick, E. L. 1978. How many cells to count? Pages 167-180 in A. Sournia, editor. Phytoplankton manual. UNESCO, Paris, France.

Wan, M. T., R. G. Watts, and D. J. Moul. 1989. Effects of different dilution water types on the acute toxicity to juvenile Pacific salmonids and rainbow trout of glyphosate and its formulated products. Bulletin of Environmental Contamination and Toxicology 43:378-385.

Wynn-Williams, D. D. 1992. Direct quantification of microbial propagules and spores. Pages 1-34 in D. D. Wynn-Williams, editor. Biotas manual of methods. Scientific Committee on Antarctic Research, Cambridge, UK.

Zaranyika, M. F., and G. M. Nyandoro. 1993. Degradation of glyphosate in the aquatic environment: an enzymatic kinetic model that takes into account microbial degradation of both free and colloidal (or sediment) particle adsorbed glyphosate. Journal of Agricultural and Food Chemistry 41:838-884.

\section{APPENDIX}

Major physical-chemistry constituents of ponds for each treatment at initial condition and after Roundup addition (Ecological Archives A017-094-A1). 